\title{
The Use of ICT in College English Teaching
}

\author{
Lang Yongqing \\ Dept. of Humanities and Social Sciences \\ Beijing Electronic Science and Technology Institute \\ Beijing, China
}

\begin{abstract}
This paper introduced an online College English Teaching and Learning System and strongly recommended the teachers to use ICT to assist their teaching and student learning. ICT holds great potential for a shift away from instructionism towards constructivism. However, technology is not everything. ICT is just a catalyst of change, it doesn't determine the direction of change.
\end{abstract}

Key words: ICT, instructionism, constructivism

\section{Introduction}

Rapid developments in information and communication technologies (ICT) in recent years have resulted in significant changes in the way the world operates and communicates. This in turn has had an impact on educational needs, both in terms of the content and the delivery of educational services. More and more teacher use technology in their teaching practice. In my school, our College English textbook is called New Horizon College English (henceforth NHCE), which is an EFL (English as a Foreign Language) coursebook series specially developed for non-English major postsecondary students in China. It is available in three media formats: printed books, CD-ROM and the website (http:/nhce.besti.edu.cn). However, some teachers seemed to have waved aside the CD-ROM and the website. They still use the traditional printed books in traditional classrooms. In this paper, I will strongly recommend them to use the technology (CD-ROM and the website) to assist their teaching and student learning because ICT has made great impacts on contemporary learning and instruction and there is no doubt our teachers are expected to keep up the time.

\section{The use of ICT in College English Teaching and Learning}

What is on the CD-ROM and the website is actually a courseware, through which students can practice their listening, speaking, reading and writing without teacher's presence. For example, they can watch a video clip of an English movie and role play it, which will be recorded by the courseware. Students can do exercises or tests on the website and the courseware can evaluate their learning.

The NHCE website was designed as follows: 


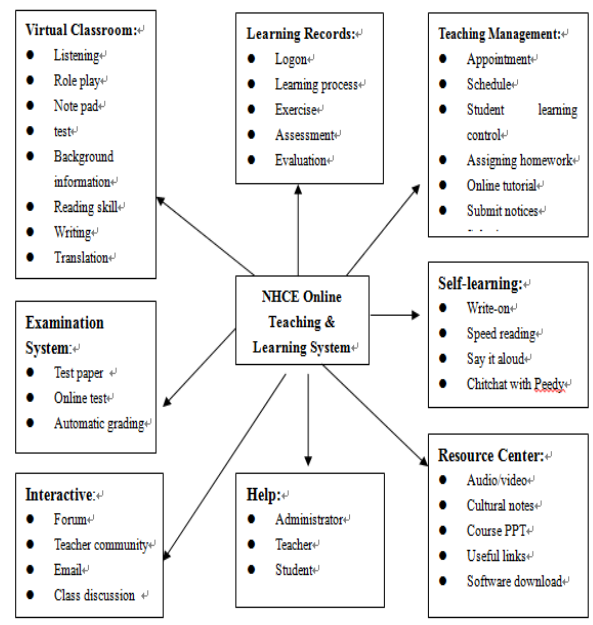

Through this system, students complete their learning activities online:

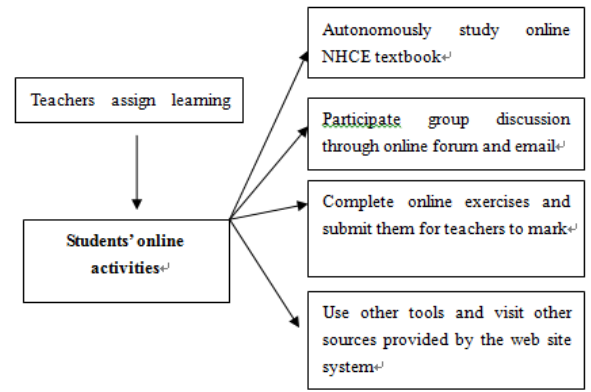

After a teacher assigns the learning tasks, for example, one unit in NHCE book, students can log onto the website or use the CD-ROM to complete the tasks. In any unit of the online NHCE course, students can listen to the audios, watch the videos and then do exercises online (including multiple choices, compound dictation, short answer questions, roleplaying, etc.) If they have any questions, they can go to the forum to discuss with their classmates and teachers, or they may visit more resources online to find out answers. From this, we can conclude the NHCE online system offers a studentcentered learning paradigm. Students decide when to learn, what to learn and how to learn.

\section{The potentials of ICT in English teaching}

With the help of NHCE online system, students can plan learning according to individual learning styles. The differentiated learning approach emphasizes the need to plan learning differently for different students, allowing them to work according to their individual learning style and learning pace (www.elearningeuropa.info, 2005). There is a great variety of Chinese students learning English. They are greatly different in learning background, interests, motivation, accent and study habits, etc. For example, in listening comprehension, some students can catch what was said in an audio file after listening just one time, others may need to listen to the audio more times before they understand. In traditional classroom, teachers have to adopt the same teaching rhythm to all students. However, if the listening practice is based on the NHCE online system, students can choose a frequency most suitable to themselves; they can customize their learning and dig out their maximal potentials or increase student productivity.

On the NHCE e-learning platform, students can practice English through the chat rooms, discuss learning experience in forums and get tutorial from their teachers. Online discussion is easier and more frequently available than in traditional classroom. All of these promote collaborative and cooperative learning. The new learning paradigm in school education focuses on social participation, hence on working with student's communication and collaboration skills (www.elearningeuropa.info, 2005). Researchers have found that the use of ICT leads to more cooperation among learners within and beyond school and a more interactive relationship between students and teachers (Reginald Gregoir inc.etal, 1996; Newhouse, 2002). 
The NHCE Online Learning and Teaching System enables students to be more active and interested in learning English. Lack of interests in English is a big problem for many Chinese students. The NHCE e-learning system does provide a lot of interesting materials and will surely arouse students' interest. They can improve their English through listening to stories or watch English movies or reading cultural tips which are available on the online system. They will be more interested in learning English. Using the online course, they are learning English by doing (practicing), not by receiving duck-force feeding in traditional classroom. Students are more likely to be interested and attentive and will achieve a wider range of learning outcomes if they can be active, learning by doing (Newhouse, 2002). Computer systems do provide the opportunity to create a wide range of interesting learning experiences (Committee on Developments in the science of Learning, 2000). This is likely to help to maintain student interest and interest a wider range of students (Cradler \& Bridgforth, 2002).

On the NHCE online platform, teachers are expected to do the following work:

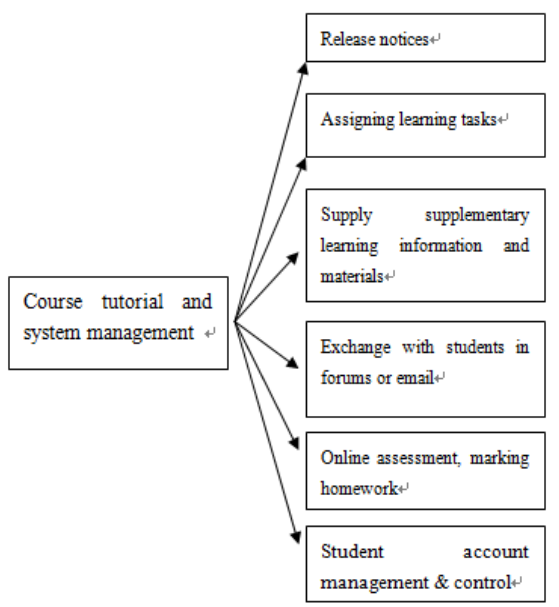

From the diagram above, NHCE online system doesn't supply a teacher-centred learning paradigm. Teachers are just material suppliers, or facilitators, or administrators, or helpers to students. Actually, this is a shift away from instructionism towards constructivism (www.elearningeuropa.info, 2005). Also, according to Newhouse, "Almost all those who advocate major reforms of schooling, particularly through the use of computers, have the view that learning needs to be more informed by constructivism(e.g. Clouse \& nelson, 2000). " Many educators have argued that the appropriate use of ICT by students can assist teachers in determining and catering for the prior knowledge of students. Further, it is usually also argued that ICT can assist students in engaging cognitively to a greater depth with knowledge domains". (Paul Newhouse, 2002, The Impact of ICT on Learning and Teaching, p7-8).

Teachers are never satisfied with their teaching and always strive to do better. Many educators believe that what is offered in school classrooms is hopelessly inadequate to match the needs of the society and the needs of individual students. And in increasing number of educators (e.g. Schlechty, 1997) are sure that part of the solution is to provide better technology support for learning environments (Newhouse, 2002). Almost every student in China is learning English because society needs talents with good command of English. There is a contradiction between the large number of English learners and the limited number of English teachers. Also language acquisition needs a lot of practice. Computer-based NHCE learning and teaching system can be really helpful.

Up to now, I have discussed several positive aspects of NHCE online system. However, every coin has two sides. Computer or technology is not everything. 
There could be some problems arising in technology use in learning.

\section{Some disadvantages of the use of ICT in teaching and learning}

Time-consuming. With this courseware, teachers may spend more time preparing class than before. They need to spend more time on familiarizing new technology. They have to spend more time monitoring students' learning records on line. Marking online takes more time than marking exercise books.

Technical disaster. Sometimes the computer is down and the network is disconnected. If technical problems arise in classrooms, teachers may need the technical people to fix it, which might spoil the class.

It's hard to control authentic learning. Although teachers prescribe tasks of selflearning, some students didn't even do the tasks really, they just click and submit randomly their answers. In fact, they are cheating by doing so, but it's hard for teachers to find who is doing like this.

Old things in new way. Some students think the courseware is just a new way to deliver boring text book information. Quite a few students still think learning English is so boring no matter what new ways teachers suggest to them. NHCE is available in three media formats: printed books, CD-ROM and the website. Schools have bought the 3 formats and developed the physical infrastructure. However, teachers are still using printed textbooks only. Some students even have never touched the $\mathrm{CD}$ attached in the textbooks. Only a few teachers and students use it or log on the website occasionally.

Accessibility and Financial problems. Quite a few students don't have a computer. In addition, the campus LAN and computer rooms in school can't guarantee students to access to computers at any place and any time.

Technological imperative (Coppola, 2005). It refers to some people depending too much on technology. They believe technology is even more important than instruction. Some teachers may think, with the introduction of NHCE e-learning system, they can cut down classroom hours and don't have to spend much time preparing for classes. Good teachers are those who can use ICT very skilfully in classrooms. At this time, they forget teaching philosophy should be the priority.

Romantic visions. Some people believe computers can replace teachers, be more efficient than teachers, increase class size, decrease cost, and motivate students (Coppola, 2005). For example, some people tend to believe the NHCE online learning system can completely solve the problem of the contradiction between the large number of English learners and the limited number of English teachers.

Competition drain (Coppola, 2005), It refers to the internal politics when teacher and students compete for the scarce resources or computer access (Coppola, 2005). Because of the shortage of computers, NHCE online system may be entitled to be only used by the so-called top students or some qualified teachers. These problems may drain energy from the primary task of the school: to develop high quality instruction (Coppola, 2005).

\section{Conclusion}

In summary, the use of ICT does have great impact on learning and instruction. It holds great potential for supporting the shift towards constructivist paradigm. Equipped with the NHCE CD-ROM and online learning system, teachers can optimize their instruction and students can 
be more active in self-learning and have better learning outcomes. However, ICT is not the determining factor to the change of learning paradigm. Technology is not everything. "ICT is often a catalyst of change, but does not in itself determine the direction of change". A better learning outcome depends on teachers' ability to use technology to support pedagogical learning objectives. A teacher with advanced pedagogical concepts as well as ICT awareness could be the best teacher.

\section{References}

[1] Alison Elliott, (2004) Information Age, When Learners know more than the teachers.
[2] C. Paul Newhouse, (2002), Literature Review, The Impact of ICT on Learning and Teaching, p.4-8, p 20 22

[3] Eileen M. Coppola, (2005), Powering up: Supporting Constructivist Teaching with Technology, p 4-6

[4] elearningeuropa.info, (2005), The New Learning Paradigm in School Education

[5] Ministry of Education of China (2004), College English Curriculum Requirements, Higher Education Press. 